\title{
Intra-specific pelage color variation in a South American small rodent species
}

\author{
M. L. Sandoval Salinas ${ }^{a, b} *$, R. M. Barquez ${ }^{b}$, E. M. Colombo ${ }^{a, c}$ and J. D. Sandoval ${ }^{a, c}$ \\ anstituto de Investigación en Luz, Ambiente y Visión - ILAV, Universidad Nacional de Tucumán - UNT, \\ Consejo Nacional de Investigaciones Científicas y Técnicas - CONICET, Av. Independencia, 1800, \\ CP 4000, San Miguel de Tucumán, Tucumán, Argentina

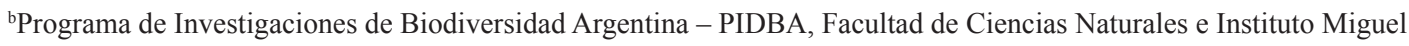 \\ Lillo - FCNeIML, Universidad Nacional de Tucumán - UNT, Miguel Lillo, 205, CP 4000, \\ San Miguel de Tucumán, Tucumán, Argentina \\ 'Departamento de Luminotecnia, Luz y Visión - DLLyV, Facultad de Ciencias Exactas y Tecnología - FaCET, \\ Universidad Nacional de Tucumán - UNT, Av. Independencia, 1800, CP 4000, \\ San Miguel de Tucumán, Tucumán, Argentina \\ *e-mail: maritisandoval@yahoo.com.ar
}

Received: January 6, 2015 - Accepted: June 19, 2015 - Distributed: August 31, 2016

(With 6 figures)

\begin{abstract}
Intra-specific color variation is often underestimated by researchers, and among mammals, intra-specific differences in coloration are poorly documented for most species. The main goal of this study was to apply an objective color measurement methodology to the study of a specific problem: the detection, if any, of patterns of changes in the fur color of specimens of Akodon budini in relation to biological (i.e., sex) and environmental (i.e., season) variables. We hypothesize that coat color will be more homogeneous in males than in females and that coat color will be darker in winter than in summer, the latter being orange. We measured the pelage color on five points over the dorsal surface of 26 A. budini museum specimens using a spectroradiometer and a diffuse illumination cabin. We used Principal Component Analysis to describe the association between the color variables, sex and season, and each of the observations. We then used general linear models of Analysis of Variance to examine relationships between color data, season, and sex. The results clearly confirm the hypothesis related to seasonal coat color change but do not directly confirm the hypothesis related to changes in coat color in relation to sex, and we show the complexity of the studied pattern. In conclusion, undoubtedly, the studied variables should accordingly be considered when studying the coloration of specimens for characterization, identification and discrimination of different taxonomic units based on color.
\end{abstract}

Keywords: Akodon budini, CIELab colour space, season, sex, spectroradiometer.

\section{Variação intraespecífica da cor da pelagem de uma espécie de pequeno roedor sul-americano}

\section{Resumo}

Variação de cor intra-específica é muitas vezes subestimada pelos pesquisadores, e entre espécies de mamíferos, as diferenças intra-específicas na coloração são pouco conhecidas para a maioria das espécies. O principal objetivo deste estudo foi aplicar uma metodologia objetiva de medição de cor para o estudo de um problema específico: a detecção de padrões de mudanças na cor da pele de espécimes de Akodon budini em relação a variáveis biológicas (i.e., sexo) e ambientais (i.e., temporada), se houver. Nossa hipótese é que a cor da pelagem do sexo masculino será mais homogênea do que a de fêmeas e que a cor da pelagem do inverno vai ser mais escura do que a de verão, sendo esta última mais laranja. Medimos a cor da pelagem em cinco pontos sobre a superfície dorsal de 26 espécimes de museu de $A$. budini usando um espectroradiômetro e uma cabine de iluminação difusa. Usamos Análise de Componentes Principais para descrever a associação entre as variáveis de cor, sexo e temporada, e cada uma das observações. Em seguida, usamos modelos lineares gerais da Análise de Variância para verificar as relações entre os dados de cor, temporada, e sexo. Os resultados confirmam claramente a hipótese relacionada à mudança sazonal de cor da pelagem, mas não confirmam diretamente a hipótese relacionada com alterações na cor da pelagem em relação ao sexo, e vamos mostrar a complexidade do modelo estudado. Em conclusão, sem dúvida, as variáveis estudadas devem consequentemente ser tidas em conta quando se estuda a coloração de amostras para caracterização, identificação e discriminação de diferentes unidades taxonômicas com base na cor.

Palavras-chave: Akodon budini, espaço de cor CIELab, temporada, sexo, spectroradiometer. 


\section{Introduction}

Akodon Meyen, 1833 is the most diverse Akodontini and Sigmodontinae genus, with 41 valid living species (Musser and Carleton, 2005), and one of wider distribution genera in the Neotropics, inhabiting landscapes from northern South America to Patagonia, mainly in Andean habitats (Reig, 1987; Smith and Patton, 1999). Over 50\% of these species have documented populations in Argentina, which constitutes the richest country for the genus (Pardiñas et al., 2006), and most of those species inhabits Northwestern Argentina. Particularly, Akodon budini (Thomas, 1918) inhabits the Yungas forests of North-western Argentina and South-central Bolivia. Unfortunately, for many species there is only a brief original description, most of which are based on few specimens (Jayat et al., 2007), and A. budini is not an exception. So, this species, as the vast majority (Pardiñas, 2009), is poorly known even in basic taxonomic and morphological aspects.

In general, prey animals have evolved a variety of visual characteristics in order to minimize detection by predators (Rowland, 2009); therefore, color patterns should be inconspicuous or cryptic against visual background (Endler, 1990).

On taxonomic and systematic studies, coat color is considered a diagnostic feature to identify several species of mammals (Caro, 2005). Although mammalian fur shows a considerable degree of inter- and intra-specific color variation, this variation is rarely empirically studied (Caro, $2005,2009)$. In particular, intra-specific color variation is often underestimated by researchers (Davis and Castleberry, 2010). In specimens of the same taxonomic unit, variations in coat color may exist in relation to several biological features, such as age (e.g., Rios and Álvarez-Castañeda, 2012), sex (e.g., Davis and Castleberry, 2010; Rios and Álvarez-Castañeda, 2012), season (e.g., Camargo et al., 2006), habitat (e.g., Heth et al., 1988; Carraway and Verts, 2002; Lai et al., 2008; Rios and Álvarez-Castañeda, 2012), etc. Moreover, in specimens collected in different years, there may be variations in coat color in relation to sample antiquity, i.e., the storage time of the specimens in a Mammalian Collection of a Natural History Museum (e.g., Davis and Castleberry, 2010; Davis et al., 2013).

Precise color measurements are a standard practice in studies of birds (Hill, 2002), but are rarely used with mammals (with some exceptions such as Sumner and Mollon, 2003; Linnen et al., 2013). In recent years, the development of improved devices for measuring specific properties of reflected light (Lozano, 1978; Schanda, 1997; Capilla et al., 2002) allows recording the specific characteristics of the light coming directly from the object under study (Grill and Rush, 2000). These devices have been increasingly used to quantify tiny variation of integument color in many animal species. Certainly, quantitative output values enable the realization of detailed statistical analyzes (Patten and Unitt, 2002). The use of spectroradiometers instead of colorimeters is recommended by some authors (Endler, 1990; Cuthill et al., 1999; to deepen on color measurement and the differences between different methods see the papers cited by Senar, 2004).

The main goal of this study was to apply an objective color measurement methodology to the detection, if any, of patterns of changes in the fur color of specimens of a small mammal species, Akodon budini, in relation to their sex and the season of the year they were collected. We aim to provide a general overview of intra-specific color variation in A. budini, trying to lay the groundwork for future studies and detailed analysis of this and other species.

\section{Material and Methods}

\subsection{Hypotheses}

The general hypotheses guiding this study are as follows:

1. The coat color of $A$. budini specimens varies with sex in a pattern of change that can be quantitatively characterized. In agreement with the results of Camargo et al. (2006) for other small mammal species, we hypothesize that coat color in males of $A$. budini will be more homogeneous than in females, probably due to the fact that males are more exposed to predation than females because they spend more time on the surface searching for territories, and, therefore, as a protective camouflage, the coat color of surviving adult males better matches background color than that of females (Camargo et al., 2006).

2. The coat color of $A$. budini varies with season in a pattern of change that can be quantitatively characterized. It has been reported (Camargo et al., 2006) for Calomys laucha, the coat color is dark in winter, and lighter and orange in summer. Since we are also studying a Southern small mammal species, we hypothesize that the coat color of $A$. budini specimens in winter will be darker than in summer, the latter being more orange.

\subsection{Materials}

We selected the sample to be studied in the Colección Mamíferos Lillo (CML, Facultad de Ciencias Naturales e Instituto Miguel Lillo, Universidad Nacional de Tucumán, Argentina) based on the following criteria: (1) It had to be represented by males and females specimens, to allow controlling the first hypothesis. (2) It had to be represented by specimens collected in different seasons, to allow controlling the second hypothesis. (3) It should be a species not widely distributed; or, if so, it had to be represented by a quantity of specimens from a small geographic area, to minimize the possibility of comparing different races or differently locally adapted animals. So, geographical origin will be a parameter -and not a variable- in the study. (4) It should not be represented by a temporally wide sample; or, if so, it had to be represented by a quantity of specimens collected in a short period of time. Storage time will be a parameter in the study. (5) It had to be represented by specimens that had all been skinned and stored in general with the same methods. Specimen preparation and storage conditions, 
as well as geographical origin and storage time, will be parameters in the study.

The sample that met all the detailed criteria was a subset of all the complete (skin and skull) A. budini museum specimens housed in the CML. These 26 specimens were collected in 1970, between November to February ( $\sim$ summer) and May to August ( winter) (see Appendix A), only from a small geographic area in the province of Jujuy, a part of all the known distributional range of the species in Argentina (which is anyway a latitudinal, longitudinal, and altitudinal restricted distributional range; see Figure 1). Although it has been reported that seasonal variations of coat color in a small South American rodent species are not influenced by the age of the individual (Camargo et al., 2006), the relationship between individual age and sex-related coloration changes is not known, so all studied specimens are adults identified by their molars being fully erupted and exhibiting wear, and their skull sutures being completely fused. We measured all available dry adult specimens because none of them were visibly molting nor were worn, dirty or grossly damaged.

To control color differences related to specimen sex and to seasonal color variation, we recorded sex and collection dates of the specimens, indicated on specimen tags. These data were later matched to specimen color data.

\subsection{Methods}

We measured the color data of the studied skins using a Photo Research PR715 spectroradiometer (capable of measuring spectral power distribution between $380 \mathrm{~nm}$ and $1068 \mathrm{~nm}$ ) calibrated against a white diffuse standard (Ocean Optics Reflectance Standard WS-1, a pressed PTFE housed in aluminum, with reflectivity $>98 \%$ in the range of 250-1500 nm) and a diffuse illumination cabin constructed at DLLyV-ILAV (rectangular diffusing white box $60 \times 60 \times 90 \mathrm{~cm}$, illuminated by four halogen lamps 12 V DC 50 WW), using SpectraWin 2 software. The spectroradiometer was mounted on a tripod, which

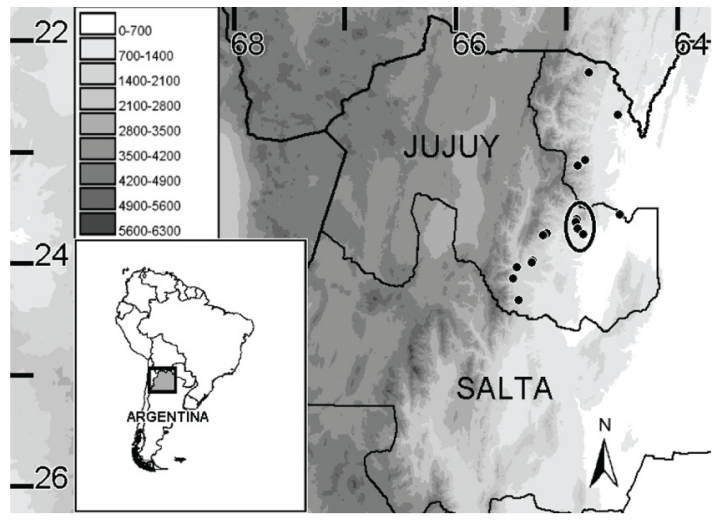

Figure 1. Map of North-western Argentina showing the occurrence records of Akodon budini taken from all the specimens housed at the Colección Mamíferos Lillo. In the circle, the occurrence records of the 26 specimens collected in the 1970 in Jujuy. maintained the instrument at a fixed distance $(\sim 1.5 \mathrm{~m})$ from, and perpendicular to, the specimen dorsal midline. This instrument measures the reflectance spectrum (the amount of incident light reflected or transmitted by an object in the different wave-bands of a specific region of the spectrum; Ruiz and Pereira, 2014) and generates a curve, i.e., reflectance values for every spectral band. These reflectance values can be used in the form of tri-stimulus values (Schanda, 2007), which may be defined according to different systems (e.g. Munsell, CIE Yxy, CIE Lab, CIE LCH; [CIE: Commission Internationale de L'Eclairages, or International Commission on Illumination]; Schanda, 1997). Calculation of these values implies and imposes the use of standard conditions for observation, e.g., different illuminants. The CIE has defined several types of standard illuminants. We worked with the CIE standard illuminant A, which is intended to represent typical, domestic, tungsten-filament lighting. Finally, the instrument provides the color data in the CIE Lab color system. In the CIE Lab color space, " $L *$ " denotes how light or dark the color is (level of lightness), while " $\mathrm{a}$ *" and " $b$ *" together indicate chromaticity. An increase in $a^{*}$ indicates more red, while a decrease indicates a movement to green; meanwhile, an increase in $b^{*}$ indicates more yellow, while a decrease indicates a movement to blue. CIE Lab color space (Schanda, 2007) is the main reference color space because it is based on the human visual model and therefore includes all of the colors perceived by humans (Ruiz and Pereira, 2014). Besides, this color space was selected because it is more appropriate for the biological aims of this study (Singaravelan et al., 2013).

We measured the spectral reflectance and recorded the chromatic coordinates of five points over the dorsal body region, namely the neck, upper back, middle back, lower back, and rump of each specimen (see Figure 2). We recorded five measurements per specimen. This measurement

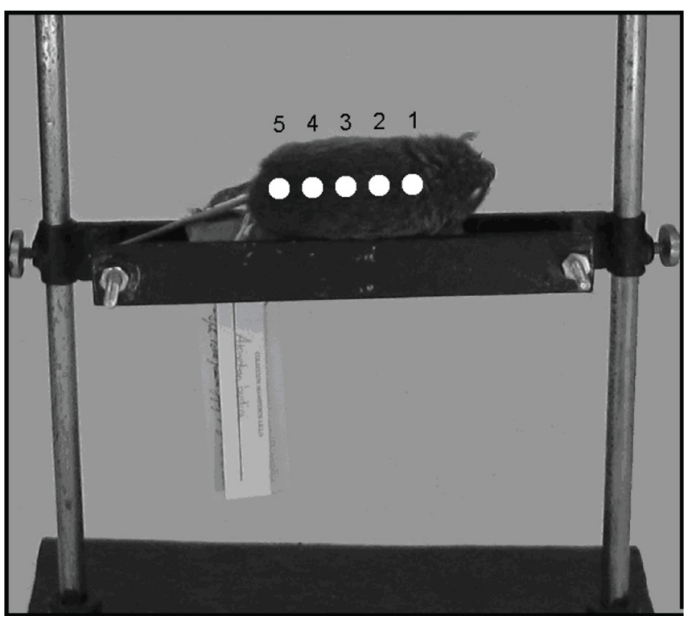

Figure 2. Photograph of a specimen of Akodon budini placed within the diffuse illumination cabin showing the five points over the dorsal body region, namely the neck, upper back, middle back, lower back, and rump, where we measured the pelage color. 
protocol was previously tested leading to obtaining very satisfactory results (Sandoval Salinas et al., in prep.).

- Statistical analyses.- Color data were handled and analyzed using two software packages: (1) The spreadsheet Microsoft Excel (2003 version) to enter and handle coordinates color data, and to make some graphs; (2) the computer statistical package INFOSTAT (2013 version) to conduct all statistical analyses and to make other graphs for the display of results.

We used Principal Component Analysis (PCA) to describe the association between the dependent variables (the color variables), the independent variables (in this case, sex and season), and each of the observations. The number of components extracted in a PCA is equal to the number of variables being analyzed. As a result of PCA, the variation in chromatic coordinates will be described by three principal components that are by definition independent (orthogonal) (Cuthill et al., 1999). All components that are extracted in the analysis display two characteristics: each component accounts for a maximal amount of variance in the observed variables that was not accounted for by the preceding components, and is uncorrelated with all of the preceding components (Sokal and Rohlf, 1981; Otto, 1999; Malinowski, 2002). To evaluate intra-specific variation we first used all specimens. Subsequently, to evaluate intra-specific variation related to sex (males versus females) we used specimens collected in winter $(n=15)$ and also specimens collected in summer $(n=13)$; and to evaluate intra-specific variation related to collection season (winter versus summer) we used male specimens $(n=20)$.

We then used general linear models of Analysis of Variance (ANOVAs) to examine relationships between color data, season, and sex. $L^{*}, a^{*}$, or $b^{*}$ was included as the dependent variable in each analysis, and specimen sex and collection season were included as independent variables (all as categorical variables). Specimen identification was included as a random effect. Interaction terms with the measuring point were also included in the analysis. We then used model simplification procedures by removing each non-significant $(\mathrm{p}>0.05)$ interaction term. We used as post hoc test the Fisher' LSD statistic with Bonferroni correction. Significance was accepted when $p<0.05$. We report results from a final analysis that includes those parameters that explain substantial variation in each response variable as determined by model fitting.

\section{Results}

\subsection{Global PCA (Tables 1 and 2)}

- Sex.- In Figure 3 dots were painted according to the sex of the specimen. By studying the relationship of dot clouds corresponding to each sex in the graph, we could not draw any definite conclusion. Dots seem to be almost equally distributed in the space defined by PC1 and 2, without having any apparent differential distribution determined by the sex of the specimen, except the apparent different amplitude of the color variation range observed in each sex (see below).

- Season.- In Figure 4 dots were painted according to the season when the specimen was collected. By studying the relationship of each season dot clouds in the graph, with respect to axis 1, we observe that most dots corresponding to specimens collected in winter are located toward the left, i.e., in the direction of decreasing values of $a^{*}$ and $b^{*}$, and to a lesser extent of $\mathrm{L}^{*}$. The opposite applies to dots corresponding to specimens collected in summer: they are located to the maximum values of $a^{*}$ and $b^{*}$, and to a lesser extent of $\mathrm{L}^{*}$. With respect to axis 2 , overlapping of both dot clouds is extensive, although some winter dots are offset to increasing PC2 values, which is not observed in any summer dot.

Table 1. Principal Component Analysis (PCA) of color variables ( $\mathrm{L}^{*}$, level of lightness, and a* and $\mathrm{b}^{*}$, chromaticity): Eigenvectors. (a) Intra-specific color variation. Data analysis of 26 Akodon budini specimens collected in the 1970. (b) Intra-specific color variation related to sex. Data analysis of 15 A. budini specimens collected in winter. (c) Intra-specific color variation related to sex. Data analysis of 13 A. budini specimens collected in summer. (d) Intra-specific color variation related to collection season. Data analysis of 20 A. budini male specimens. Vs: Variables; e1, e2, e3: eigenvectors 1, 2, and 3, respectively; $(-)$ winter data; $(+)$ summer data.

(a)

26 Akodon budini specimens collected in the 1970 in Jujuy

(b)

15 Akodon budini specimens collected in winter

(c)

13 Akodon budini specimens collected in summer

(d)

20 Akodon budini male specimens

\begin{tabular}{ccrc} 
Vs & e1 & e2 & e3 \\
\hline L $^{*}$ & 0.54 & 0.84 & -0.03 \\
$\mathrm{a}^{*}$ & 0.59 & -0.41 & -0.69 \\
$\mathrm{~b}^{*}$ & 0.60 & -0.36 & 0.72 \\
\hline $\mathrm{L}^{*}{ }_{-}$ & 0.53 & 0.85 & -0.04 \\
$\mathrm{a}^{*}-$ & 0.60 & -0.40 & -0.69 \\
$\mathrm{~b}^{*}-$ & 0.60 & -0.34 & 0.72 \\
\hline $\mathrm{L}^{*+}$ & 0.53 & 0.76 & -0.38 \\
$\mathrm{a}^{*+}$ & 0.56 & -0.65 & -0.52 \\
$\mathrm{~b}^{*+}$ & 0.64 & -0.06 & 0.77 \\
\hline $\mathrm{L}^{*}$ & 0.54 & 0.84 & -0.01 \\
$\mathrm{a}^{*}$ & 0.59 & -0.39 & -0.70 \\
$\mathrm{~b}^{*}$ & 0.60 & -0.37 & 0.71 \\
\hline
\end{tabular}


Table 2. Principal Component Analysis (PCA) of color variables: Eigenvalues. (a) Intra-specific color variation. Data analysis of 26 Akodon budini specimens collected in the 1970 in Jujuy. (b) Intra-specific color variation related to sex. Data analysis of $15 \mathrm{~A}$. budini specimens collected in winter. (c) Intra-specific color variation related to sex. Data analysis of $13 \mathrm{~A}$. budini specimens collected in summer. (d) Data analysis of 20 A. budini male specimens. (-) Winter data; $(+)$ summer data.

\begin{tabular}{lcccc}
\hline & Lambda & Value & Proportion & Cum Prop \\
\hline \multirow{2}{*}{ (a) } & 1 & 2.49 & 0.83 & 0.83 \\
& 2 & 0.37 & 0.12 & 0.96 \\
\hline \multirow{2}{*}{ (b) } & 3 & 0.13 & 0.04 & 1.00 \\
\hline 5 Akodon budini specimens collected in winter & $1-$ & 2.46 & 0.82 & 0.82 \\
& $2-$ & 0.44 & 0.44 & 0.97 \\
(c) & $3-$ & 0.10 & 0.03 & 1.00 \\
13 Akodon budini specimens collected in summer & $1+$ & 2.26 & 0.75 & 0.75 \\
& $2+$ & 0.60 & 0.20 & 0.95 \\
(d) & $3+$ & 0.14 & 0.05 & 1.00 \\
20 Akodon budini male specimens & 1 & 2.33 & 0.78 & 0.78 \\
& 2 & 0.53 & 0.18 & 0.95 \\
\hline
\end{tabular}

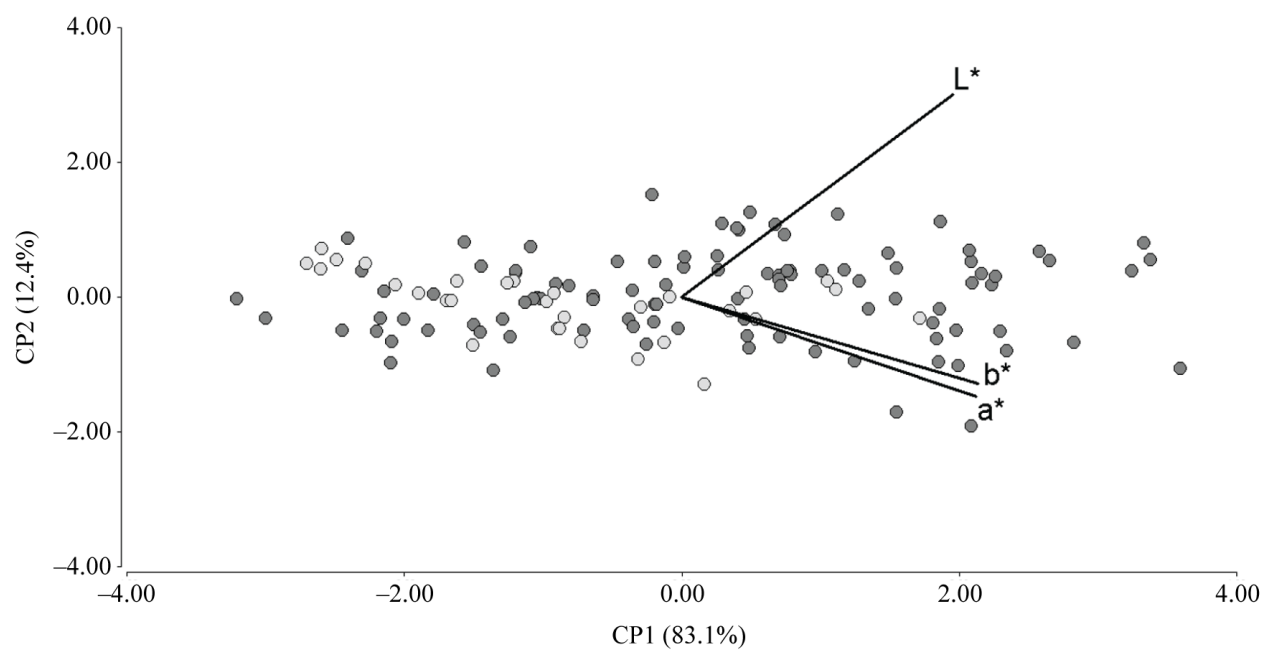

Figure 3. Global PCA: L*, a*, and $b^{*}$ values obtained for the five measuring points from 26 specimens. Dots were painted according to the sex of the specimen they belong to. Dark gray: male specimens; Light gray: female specimens.

\subsection{Partial PCAs (Tables 1 and 2)}

- Sex.- Even by eliminating the influence of season variable, it is not possible to detect clear differences in the dorsal coloration of specimens of different sex. The only tendency that is apparent is the different amplitude of the color variation range observed in each sex. Color variation in males is wider than in females; i.e., even though the two analyzed subgroups are completely overlapped, males display more extreme coat colorations (see Figure 5; Tables 1 and 2).

- Season.- By eliminating the influence of sex variable, the distinct dorsal coloration of specimens collected in different seasons becomes evident. We identified a clear tendency for specimens collected in summer to have markedly higher values of the three colorimetric variables we are studying (see Figure 6; Tables 1 and 2).

\subsection{ANOVA}

Without considering the interactions, sex does not have a significant individual effect on any of the color variables, $\mathrm{L}^{*}, \mathrm{a}^{*}$, or $\mathrm{b}^{*}$. Otherwise, there is always a significant effect of the season on color variables (Table 3 ).

- Sex.- Color data measured in males and females are not significantly different. This result was found for the three color variables (Table 3 ). However, we found significant interactions between sex and measuring point for $a^{*}$ and $b^{*}$ (Table 3). This indicates that chromaticity (i.e., $\mathrm{a}^{*}$ and $\mathrm{b}^{*}$ ) changes in relation to measuring points occur at significantly different rates in specimens of different sex. 


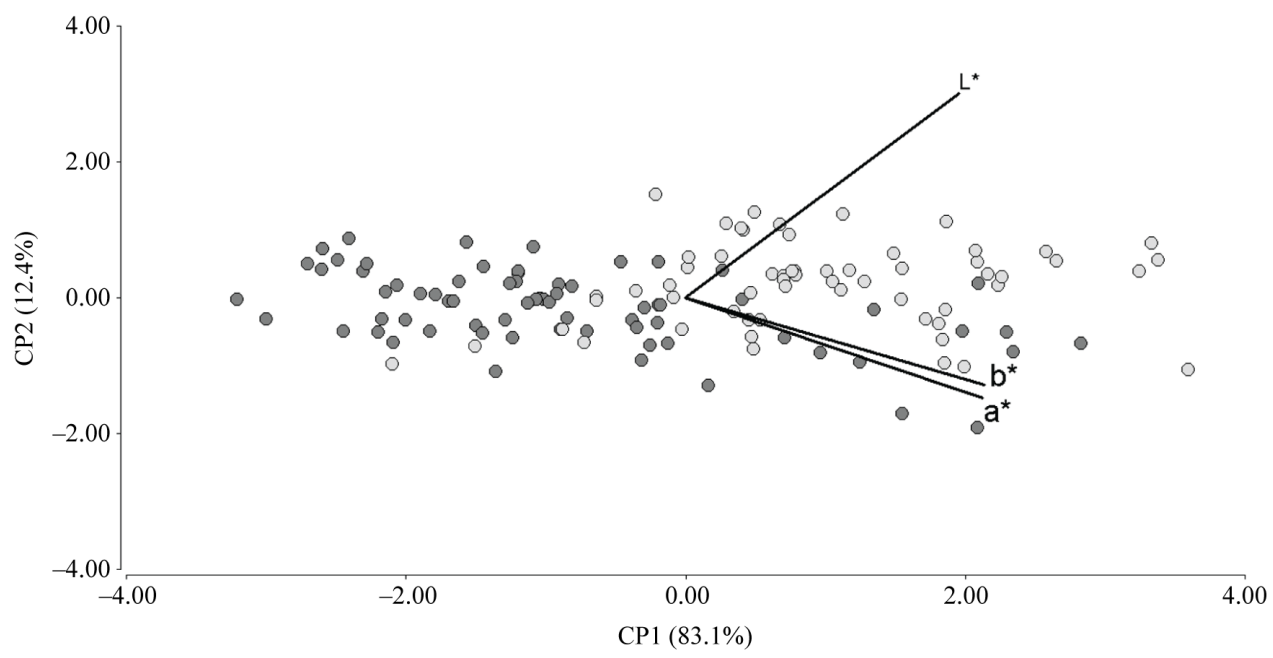

Figure 4. Global PCA: $L^{*}, a^{*}$, and $b^{*}$ values obtained for the five measuring points from 26 specimens. Dots were painted according to the season in which was collected the specimen they belong to. Dark gray: winter specimens; Light gray: summer specimens.

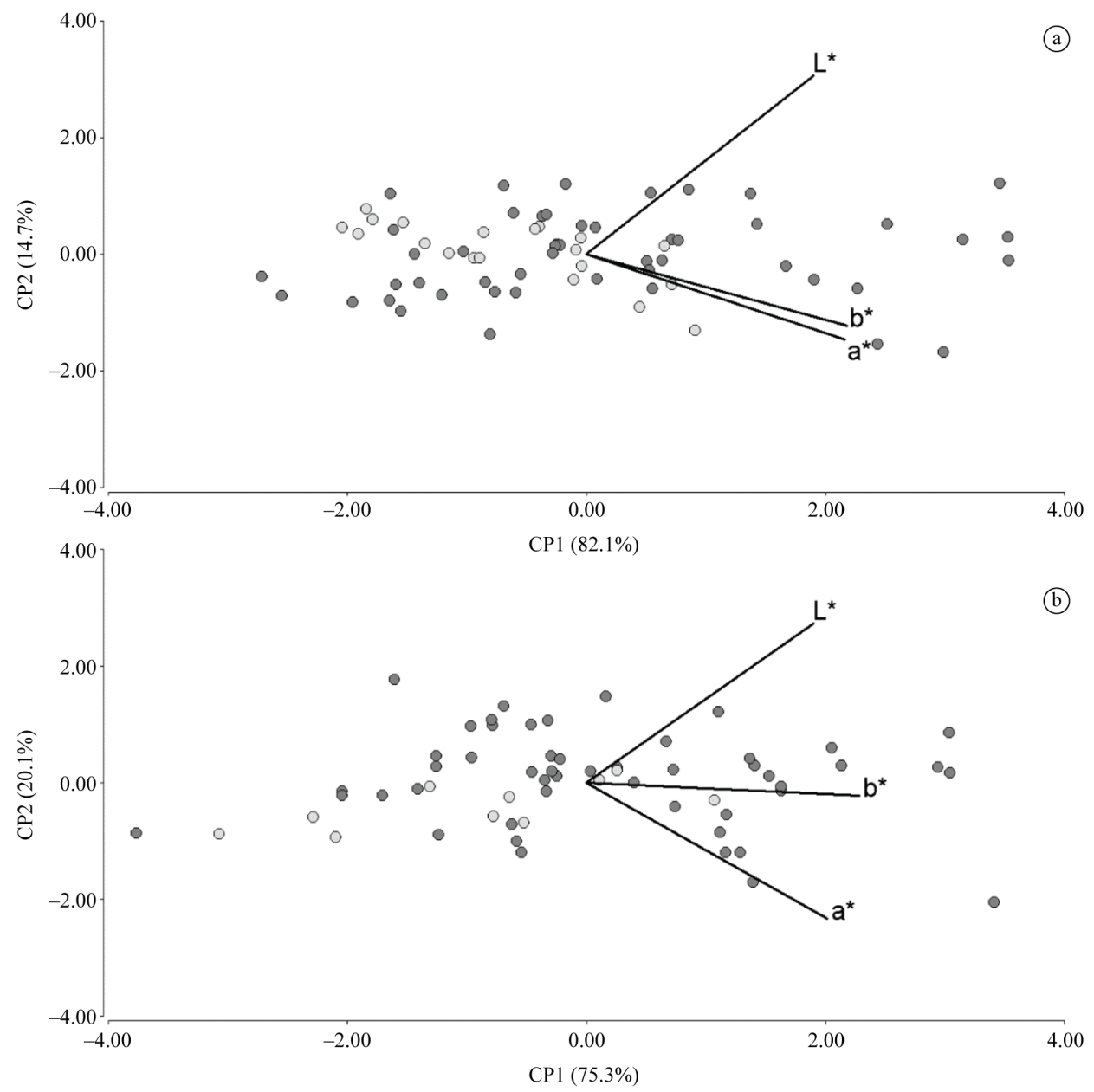

Figure 5. Partial PCA: L*, a*, and $b^{*}$ values obtained for the five measuring points from the specimens. Dots were painted according to the sex of the specimen they belong to. Dark gray: male specimens; Light gray: female specimens. (a) 15 winter specimens; (b) 13 summer specimens. 


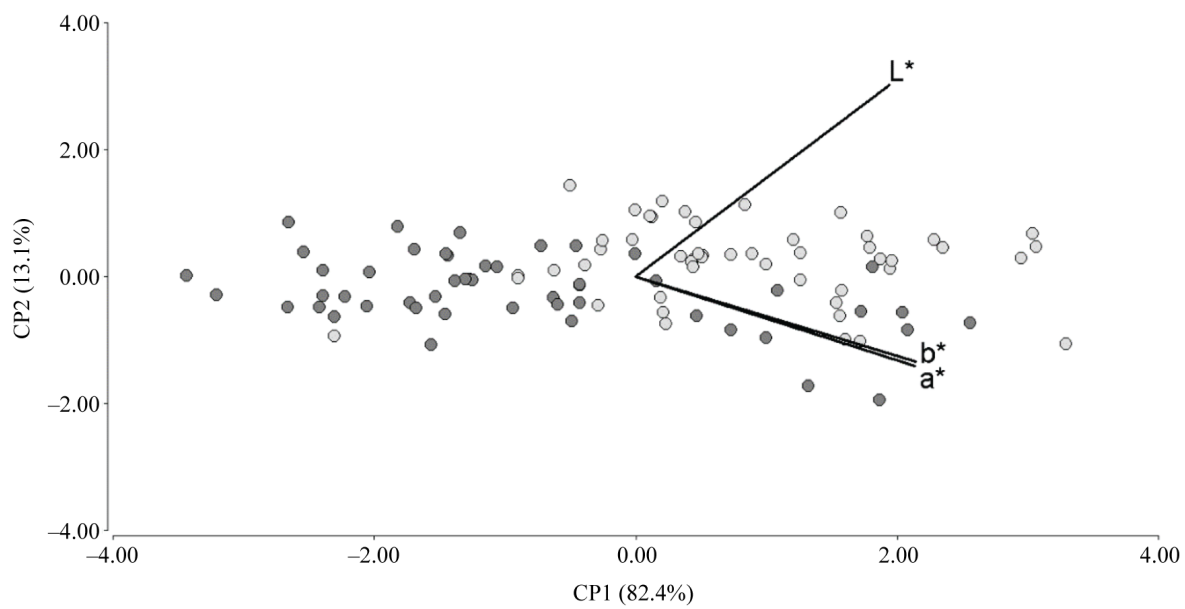

Figure 6. Partial PCA: L*, $a^{*}$, and $b^{*}$ values obtained for the five measuring points from 20 specimens. Dots were painted according to the season in which was collected the specimen they belong to. Dark gray: winter specimens; Light gray: summer specimens.

Table 3. Results from three ANOVAs in which the variation in $\mathrm{L}^{*}, \mathrm{a}^{*}$, and $\mathrm{b}^{*}$ of the dorsal fur color of Akodon budini specimens in relation to sex and collection season are shown. Variation related to measuring point is not analyzed. Separate analyses were performed with $\mathrm{L}^{*}, \mathrm{a}^{*}$, or $\mathrm{b}^{*}$ as the dependent variable.

\begin{tabular}{|c|c|c|c|c|c|c|}
\hline & \multicolumn{2}{|c|}{$\mathbf{L}^{*}$} & \multicolumn{2}{|c|}{$a^{*}$} & \multicolumn{2}{|c|}{ b* } \\
\hline & F-value & p-value & F-value & p-value & F-value & p-value \\
\hline Sex & - & - & 0.07 & 0.7912 & 0.14 & 0.7153 \\
\hline Season & 66.98 & $<0.0001$ & 3.13 & 0.0903 & 2.88 & 0.1028 \\
\hline Point & 15.84 & 0.0002 & 0.17 & 0.6789 & 42.87 & $<0.0001$ \\
\hline Sex $\times$ Season & - & - & 0.13 & 0.7214 & & \\
\hline Sex $\times$ Point & - & - & 4.79 & 0.0316 & 3.69 & 0.0582 \\
\hline Season $\times$ Point & 9.55 & 0.0028 & 14.87 & 0.0002 & 5.01 & 0.0281 \\
\hline
\end{tabular}

- Season.- Color data measured in specimens collected in winter and summer are significantly different. This result was found for the three color variables (Table 3). Moreover, we always found significant interactions between season and measuring point (Table 3). This indicates that chromaticity (i.e., $a^{*}$ and $b^{*}$ ) and lightness (i.e., $\mathrm{L}^{*}$ ) changes in relation to measuring points occur at significantly different rates in specimens collected in different seasons. This is, the slopes of the lines connecting the measuring points are significantly different in the specimens collected in winter, compared to those collected in summer. Regarding $\mathrm{L}^{*}$, the winter pelage slopes are much less pronounced than the summer ones, which are steeply negative, but the opposite is observed for $\mathrm{a}^{*}$, the summer pelage slopes being zero or slightly positive. Finally, regarding $b^{*}$, the winter pelage slopes are strongly negative meanwhile the summer pelage slopes are only weakly negative.

\section{Discussion}

This study shows a number of associations between individual pelage color variation of Akodon budini and biological (i.e., sex) and environmental (i.e., season) variables. The results clearly confirm the hypothesis related to seasonal coat color change but do not directly confirm the hypothesis related to changes in coat color in relation to sex (see below). Regrettably, as mentioned, the knowledge regarding the biology and ecology of the species of the genus Akodon in Argentina is scarce, as it is in other areas of its distribution (Queirolo and Granzinolli, 2009). Particularly, nothing is known about the natural history of Akodon budini. So, we can only speculate, suggesting analogies with other better studied sigmodontine species, in order to interpret our results and to suggest possible directions for future work.

One of the patterns of interest we found was the overall difference in pelage color range amplitude between males and females, which to our knowledge was not previously reported. Indeed, cursory observation of museum specimens does not allow detecting the subtle degree of variation in the coat color range among sexes (Sandoval Salinas, pers. obs.). So, this finding was very intriguing, and we can offer little speculation into its cause until there is further investigation over this topic. Based on the hypothesis that different parts of the body in different mammal species are subject to several selective pressures, pelage coloration has a great adaptive importance (Caro, 2005). The three most important adaptive functions of pelage are concealment 
(or crypsis or camouflage), communication (in which color patterns should be as conspicuous as possible), and regulation of physiological processes (e.g., by affecting temperature exchange with the environment) (Caro, 2005, and references therein). In relation with these functions, there are alternative explanations for sex differences in pelage color. In the case of $A$. budini, the difference is probably related to differential physiological or ecological fitness of individuals across the range of pelage colors, or to pelage color as a visual signal to conspecifics of (or a consequence of) optimal or suboptimal health (Davis and Castleberry, 2010, and references therein). Whatever the cause, adult female coloration was more uniform than that of adult males, a pattern exactly opposite to that reported by Rios and Álvarez-Castañeda (2012). Given that $A$. budini adult female dispersal is supposed to be less common (in analogy with the statement by Rios and Álvarez-Castañeda, 2012), males should be more vulnerable to above ground predation (because they spend more time on the surface searching for territories), and therefore extreme colors should be more vulnerable to predation (Rios and Álvarez-Castañeda, 2012). Prima facie, our result seems to contradict this hypothesis of stronger negative selection on males. However, if we consider that Akodon budini inhabits between 1000 and $2800 \mathrm{~m}$ (Jayat et al., 2006), with a great environment diversity at micro-scale, maybe the wider male coat color range is related to male individuals phenotypically adapted to this micro-scale diversity, even in macro-scale homogeneous landscapes. Following Lai et al. (2008), who state that precipitation determines the environmental background color, male individuals moving between micro environments with higher precipitations (and therefore higher vegetation density and darker soil color, i.e., darker background color) and micro environments with lower precipitations (and therefore lower vegetation density and lighter soil color, i.e., lighter background color) are continuously subjected to constantly changing selection pressures and may therefore find fit with the environment both at one end of the range (the darker) as at the other (the lighter) or somewhere in between throughout the all range of color variation.

Seasonal alterations in organisms are important to anticipate environmental changes and to adjust to modifications occurring throughout the year and, in mammals, molt (with pelage color change) and weight changes prepare the animal for winter or summer (Camargo et al., 2006). Thereby, seasonal coat color variation in a species with tropical-subtropical distribution, such as Akodon budini, is an expected result. According to Camargo et al. (2006, p. 84),

[...] animals which display pelage color changes become pigmented during the summer, due to melanin production by the hair bulb melanocytes. During the winter molt, the pigment production stops or is highly reduced, and as a consequence, the hair and coat turn white.

Coat color variations observed in $A$. budini are much more subtle, though no less evident, and they are very similar to those reported by Camargo et al. (2006) for Calomys laucha, with the summer pelage being more orange and lighter and the winter being darker. Likely, the brown hair color of $A$. budini is attained via a mixing of eumelanin and pheomelanin, as is seen in other small mammal species (Singaravelan et al., 2010). It is possible that the mechanism postulated for $C$. laucha by these authors, is also responsible for the seasonal coat color changes in A. budini, and thus there would be

[...] no arrest of pigment production, but a change of melanin type. During the summer molt there might be a high production of phaeomelanin and low production of eumelanin [...] whereas during the winter molt a high production of eumelanin and low production of phaeomelanin lead to a gray and darker pelage (Camargo et al., 2006, p. 84).

As mentioned, in the NWA Akodon budini inhabits exclusively in the Yungas (Pardiñas et al., 2006). This phytogeographic province includes seasonal landscapes (particularly the montane forests) and, considering that pelage color in small mammals may have a cryptic function to avoid predation (Heth et al., 1988), matching a seasonally variable background may also be the adaptive function of $A$. budini color change, as was suggested for C. laucha (Rios and Álvarez-Castañeda, 2012). Besides, as Lai et al. (2008) and Rios and Álvarez-Castañeda (2012) highlighted, thermoregulation may also play a role (winter darker coat contributing to maintain more efficiently body temperature; Cloudsley-Thompson, 1999; Caro, 2005).

All these hypotheses may be tested in future studies, opening a promising perspective to the study of natural history of rodent species. Certainly, we think it is important not only improving the measurement of traditional morphological variables such as coat color (e.g., by means of an objective methodology), but also providing additional biologically meaningful relationships between these variables and other organismic, environmental, and/or ecological attributes.

In conclusion, undoubtedly, considering our and other previous results, we believe the studied variables must be accordingly considered when studying the color of specimens for characterization, identification and discrimination of different taxonomic units based on color. The knowledge and understanding of color variation in relation to sex and collection season could allow researchers to correctly interpret the coloration of different specimens and to evaluate the observed differences in an appropriate frame of interpretation, in order to accurately determine the limits of the ranges of variation of the color of a given entity, and to establish the usefulness of such ranges in identifying different animal species, subspecies, and even populations.

\section{Acknowledgements}

We thank Elena Bru (Centro de Referencia para Lactobacilos -CERELA, Argentina) for her help with statistical analysis. MLSS is grateful to the Consejo Nacional de Investigaciones Científicas y Técnicas (CONICET, Argentina) for providing her doctoral and postdoctoral fellowships. Finally, we want 
to emphasize the enormous potential value of Biological Collections housed in Natural History Museums and available for study.

\section{References}

CAMARGO, C.R., COLARES, E. and CASTRUCCI, A.M.L., 2006. Seasonal pelage color change: news based on a South American rodent. Anais da Academia Brasileira de Ciências, vol. 78, no. 1, pp. 77-86. http://dx.doi.org/10.1590/S0001-37652006000100009. PMid:16532209.

CAPILLA, P., ARTIGAS, J.M. and PUJOL, J., 2002. Fundamentos de colorimetría. Valencia: Universidad de Valencia.

CARO, T., 2005. The adaptive significance of coloration in mammals. Bioscience, vol. 55, no. 2, pp. 125-136. http://dx.doi. org/10.1641/0006-3568(2005)055[0125:TASOCI]2.0.CO;2.

CARO, T., 2009. Contrasting coloration in terrestrial mammals. Philosophical Transactions of the Royal Society of London. Series B, Biological Sciences, vol. 364, no. 1516, pp. 537-548. http:// dx.doi.org/10.1098/rstb.2008.0221. PMid:18990666.

CARRAWAY, L.N. and VERTS, B.J., 2002. Geographic variation in pelage color of piñon mice Peromyscus truei in the northern great basin and environs. Western North American Naturalist, vol. 62 , pp. $458-465$.

CLOUDSLEY-THOMPSON, J.L., 1999. Multiple factors in the evolution of animal coloration. Naturwissenschaften, vol. 86, no. 3, pp. 123-132. http://dx.doi.org/10.1007/s001140050584. PMid:10189630.

CUTHILL, I.C., BENNETT, A.T.D., PARTRIDGE, J.C. and MAIER, E.J., 1999. Plumage reflectance and the objective assessment of avian sexual dichromatism. American Naturalist, vol. 160, no. 2, pp. 183-200. http://dx.doi.org/10.1086/303160.

DAVIS, A.K. and CASTLEBERRY, S.B., 2010. Pelage color of red bats Lasiurus borealis varies with body size: an image analysis of museum specimens. Current Zoology, vol. 56, pp. 401-405.

DAVIS, A.K., WOODALL, N., MOSKOWITZ, J.P., CASTLEBERRY, N. and FREEMAN, B.J., 2013. Temporal change in fur color in museum specimens of mammals: reddish-brown species get redder with storage time. International Journal of Zoology, vol. 2013, pp. 1-6. http://dx.doi.org/10.1155/2013/876347.

ENDLER, J.A., 1990. On the measurement and classification of color in studies of animal color patterns. Biological Journal of the Linnean Society. Linnean Society of London, vol. 41, no. 4, pp. 315-352. http://dx.doi.org/10.1111/j.1095-8312.1990.tb00839.x.

GRILL, C.P. and RUSH, V.N., 2000. Analysing spectral data: comparison and application of two techniques. Biological Journal of the Linnean Society. Linnean Society of London, vol. 69, no. 2 , pp. 121-138. http://dx.doi.org/10.1111/j.1095-8312.2000.tb01194.x.

HETH, G., BEILES, A. and NEVO, E., 1988. Adaptive variation of pelage color within and between species of the subterranean mole rat Spalax ehrenbergi in Israel. Oecologia, vol. 74, no. 4, pp. 617-622. http://dx.doi.org/10.1007/BF00380062.

HILL, G.E., 2002. A red bird in a brown bag: the function and evolution of colorful plumage in the house finch. New York: Oxford University Press.

JAYAT, J.P., ORTIZ, P.E., PARDIÑAS, U.F.J. and D’ELÍA, G., 2007. Redescripción y posición filogenética del ratón selvático Akodon sylvanus (Rodentia: Cricetidae: Sigmodontinae). Mastozoología Neotropical, vol. 14, pp. 201-225.

JAYAT, J.P., ORTIZ, P.E., TETA, P., PARDIÑAS, U.F.J. and D'ELÍA, G., 2006. Nuevas localidades argentinas para algunos roedores sigmodontinos (Rodentia: Cricetidae). Mastozoología Neotropical, vol. 13, pp. 51-67.

LAI, Y.-C., SHIROISHI, T., MORIWAKI, K., MOTOKAWA, M. and YU, H.-T., 2008. Variation of coat color in house mice throughout Asia. Journal of Zoology, vol. 274, no. 3, pp. 270-276. http://dx.doi.org/10.1111/j.1469-7998.2007.00382.x.

LINNEN, C.R., POH, Y.-P., PETERSON, B.K., BARRETT, R.D.H., LARSON, J.G., JENSEN, J.D. and HOEKSTRA, H.E., 2013. Adaptive evolution of multiple traits through multiple mutations at a single gene. Science, vol. 339, no. 6125, pp. 13121316. http://dx.doi.org/10.1126/science.1233213. PMid:23493712.

LOZANO, R.D., 1978. El color y su medición. Buenos Aires: América Lee.

MALINOWSKI, E.R., 2002. Factor analysis in Chemistry. 3rd ed. New York: John Wiley \& Sons.

MUSSER, G.M. and CARLETON, M.D., 2005. Superfamily muroidea. In: D.E. WILSON and D.M. REEDER. Mammal species of the world: a taxonomic and geographic reference. $3 \mathrm{rd}$ ed. Baltimore: Johns Hopkins University Press, pp. 894-1531.

OTTO, M., 1999. Chemometrics: statistics and computer application in analytical chemistry. New York: John Wiley \& Sons.

PARDIÑAS, U.F.J., 2009. El género Akodon (Rodentia: Cricetidae) en Patagonia: estado actual de su conocimiento. Mastozoología Neotropical, vol. 16, pp. 135-152.

PARDIÑAS, U.F.J., D’ELÍA, G., TETA, P., ORTIZ, P., JAYAT, P., and CIRIGNOLI, S., 2006. Tribu Akodontini Vorontsov, 1959 (sensu D'Elía, 2003). In: R.M. BARQUEZ, M.M. DÍAZ and R.A. OJEDA. Mamíferos de Argentina: sistemática y distribución. Mendoza: SAREM, pp. 146-166.

PATTEN, M.A. and UNITT, P., 2002. Diagnosability versus mean difference of sage sparrow subspecies. The $A u k$, vol. 119, no. 1, pp. 26-35. http://dx.doi.org/10.1642/0004-8038(2002)119[0026:DV MDOS]2.0.CO;2.

QUEIROLO, D. and GRANZINOLLI, A.M., 2009. Ecology and natural history of Akodon lindberghi (Rodentia, Sigmodontinae) in southeastern Brazil. Iheringia: Série Zoologia, vol. 99, pp. 189-193.

REIG, O.A., 1987. An assessment of the systematics and evolution of the Akodontini, with the description of new fossil species of Akodon (Cricetidae: Sigmodontinae). In: B.D. PATTERSON, and R. TIMM. Studies in Neotropical mammalogy: essays in honor of Philip Hershkovitz. Chicago: Field Museum of Natural History, pp. 347-399. Fieldiana Zoology New Series, no. 39.

RIOS, E. and ÁLVAREZ-CASTAÑEDA, S.T., 2012. Pelage color variation in pocket gophers (Rodentia: Geomyidae) in relation to sex, age and differences in habitat. Mammalian Biology, vol. 77, no. 3, pp. 160-165. http://dx.doi.org/10.1016/j.mambio.2011.12.003.

ROWLAND, H.M., 2009. From Abbott Thayer to the present day: what have we learned about the function of countershading? Philosophical Transactions of the Royal Society of London. Series B, Biological Sciences, vol. 364, no. 1516, pp. 519-527. http:// dx.doi.org/10.1098/rstb.2008.0261. PMid:19000972.

RUIZ, J.F. and PEREIRA, J., 2014. The colours of rock art. Analysis of colour recording and communication systems in 
rock art research. Journal of Archaeological Science, vol. 50, pp. 338-349. http://dx.doi.org/10.1016/j.jas.2014.06.023.

SCHANDA, J., 2007. Colorimetry: understanding the CIE system. Hoboken: John Wiley \& Sons.

SCHANDA, J.D., 1997. Colorimetry. In: C. DECUSATISIS. Handbook of applied photometry. Woodbury: AIP Press, chap. 9, pp. 327-412.

SENAR, J.C., 2004. Mucho más que plumas. Barcelona: Institut de Cultura de Barcelona. Monografies del Museu de Ciències Naturals, no. 2.

SINGARAVELAN, N., PAVLICEK, T., BEHARAV, A., WAKAMATSU, K., ITO, S. and NEVO, E., 2010. Spiny mice modulate eumelanin to pheomelanin ratio to achieve cryptic coloration in "Evolution Canyon," Israel. PLoS One, vol. 5, no. 1, pp. e8708. http://dx.doi.org/10.1371/journal.pone.0008708. PMid:20090935.
SINGARAVELAN, N., RAZ, S., TZUR, S., BELIFANTE, S., PAVLICEK, T., BEILES, A., ITO, S., WAKAMATSU, K. and NEVO, E., 2013. Adaptation of pelage color and pigment variations in Israeli subterranean blind mole rats, Spalax ehrenbergi. PLoS One, vol. 8, no. 7, pp. e69346. http://dx.doi.org/10.1371/journal. pone.0069346. PMid:23935991.

SMITH, M.F. and PATTON, J.L., 1999. Phylogenetic relationships and the radiation of sigmodontine rodents in South America: evidence from cytochrome b. Journal of Mammalian Evolution, vol. 6, no. 2, pp. 89-128. http://dx.doi.org/10.1023/A:1020668004578.

SOKAL, R.R. and ROHLF, F.J., 1981. Biometry. The principles and practice of statistics in biological research. 2 nd ed. New York: W.H. Freeman and Company.

SUMNER, P. and MOLLON, J.D., 2003. Colors of primate pelage and skin: objective assessment of conspicuousness. American Journal of Primatology, vol. 59, no. 2, pp. 67-91. http://dx.doi. org/10.1002/ajp.10066. PMid:12619048. 
Appendix A. Studied material of Akodon budini.

Examined specimens of the species included in this study. Specimens are individualized by the acronym of the collection or collector and the number that corresponds to them in the collection or collector catalog. CML is the acronym of the Colección Mamíferos Lillo -CML- (Facultad de Ciencias Naturales and Instituto Miguel Lillo, Universidad Nacional de Tucumán, Argentina). Specimens are arranged according to their sex and collection season.

Akodon budini

Collection year: 1970 - Geographical origin: Jujuy province:

Males:

Winter $70 \mathrm{~s}(\mathrm{n}=10)$

CML 1776, CML 1789, CML 1790, CML 1791, CML 1792, CML 1793, CML 1794, CML 1797, CML 1798, CML 1807

Summer: $70 \mathrm{~s}(\mathrm{n}=10)$

CML 1738, CML 1739, CML 1740, CML 1741, CML 1743, CML 1747, CML 1748, CML 1749, CML 1750, CML 1751

Females:

Winter: $70 \mathrm{~s}(\mathrm{n}=4)$

CML 1799, CML 1800, CML 1801, CML 1806

Summer: $70 \mathrm{~s}(\mathrm{n}=3)$

CML 1744, CML 1745, CML 1746. 